\title{
A DOCÊNCIA EM “CELAS DE AULA”: DESAFIOS DOS PROFESSORES DE EDUCAÇÃO FÍSICA EM ESCOLAS PRISIONAIS
}

\author{
TEACHING IN 'CLASS CELLS': CHALLENGES OF PHYSICAL EDUCATION TEACHERS IN SCHOOLS IN PRISON
}

DOCENCIA EN "CELAS DE CLASE": DESAFÍOS DE LOS PROFESORES DE LA EDUCACIÓN FÍSICA EN LAS ESCUELAS PRISIONALES

\author{
CUSTODIO, Glauber Cesar Cruz \\ NUNES, Célia Maria Fernandes ${ }^{3}$
}

\section{RESUMO}

Esta pesquisa buscou investigar possíveis desafios enfrentados por professores de Educação Física em escolas prisionais. Trata-se de uma pesquisa qualitativa que utilizou como instrumento para a coleta de dados entrevista semiestruturada, questionário e caderno de campo. Os docentes revelaram vários desafios, destacando-se os limites para o desenvolvimento de suas ações com a Educação Física, em razão das aulas acontecerem somente dentro da sala/cela e com diversas restrições. Essa situação limita o alcance dos propósitos educacionais da disciplina, em razão de suas ncessidades, e estabelecem um paradoxo, pois quando se pensa na mesma pressupõe a presença de movimento e práticas corporais

Palavras-chave: Docência em prisão. Educação Física. Escolas prisionais. Educação na prisão. Educação prisional

\section{ABSTRACT}

This research sought to investigate possible challenges faced by physical education teachers in prison schools. This is a qualitative research that used as an instrument for data collection semi-structured interview, questionnaire and field notebook. Teachers revealed several challenges, highlighting the limits for the development of their actions with Physical Education, because the classes happen only inside the room / cell and with various restrictions. This situation limits the scope of the educational purposes of the discipline by reason of their needs and establishes a paradox, because when one thinks of it, it presupposes the presence of bodily movements and practices.

Keywords: Teaching in prison. Physical Education. Schools in prison. Education in prison.

\section{RESUMEN}

En la Educación prisional se ofrecen diversas disciplinas, entre ellas la Educación Física. Este artículo presenta datos de una investigación que buscó investigar posibles desafíos enfrentados por profesores de Educación Física en escuelas prisionales. En el caso de la educación física, los profesores de la educación física, en particular, en el aula y en las diversas restricciones. Esta situación limita al alcance de los propósitos educativos de la disciplina en virtud de sus necesidades específicas, y establecen una paradoja, pues cuando se piensa en la disciplina presupone la presencia de movimiento y prácticas corporales.

Palabras clave: Docencia en prisión. Educación Física. Escuelas prisioneras. Educación en la prisión. Educación prisional.

\footnotetext{
1 A pesquisa que deu origem a este artigo contou com o apoio da Capes

2 Universidade Federal de Ouro Preto - UFOP - Ouro Preto - Minas Gerais - Brasil

${ }^{3}$ Universidade Federal de Ouro Preto - UFOP - Ouro Preto - Minas Gerais - Brasil
} 


\section{INTRODUÇÃO}

No decorrer da história, diferentes eventos e documentos oficiais expressaram e reafirmaram, mundialmente, o direito de todos os seres humanos à educação. A educação prisional surge como uma dimensão do direito a educação, sendo regida por variados documentos oficiais que, ao longo da história, expressaram de maneira implícita ou explícita o direito à educação dos sujeitos em situação de privação de liberdade.

Cumpre destacar, inicialmente, a Declaração Universal dos Direitos Humanos, aprovada no ano de 1848. Este documento, em sua resolução 217 A III, já discorria que "todo ser humano tem direito a educação" (NAÇÕES UNIDAS, 1948), sendo, nessa data, a educação obrigatória ainda nos graus elementares e fundamentais.

A partir dessa Declaração, busca-se agora compreender a oferta dessa modalidade educacional no Brasil à luz da categoria analítica que é o Direito à Educação. Para tanto, cumpre aqui descrever que a Constituição Federal de 1988, reconhece em seu artigo 205 que a Educação é um direito de todos e dever do Estado, garantindo o direito constitucional de todas as pessoas à educação, visando seu pleno desenvolvimento.

Para além da Constituição Federal, outros marcos legais vão balizar à educação prisional, como pode se citar a Lei de Execução Penal (lei 7.210/84), que representa uma diretriz muito importante no que se refere ao direito à educação prisional. Em seu artigo 18, é exposto a obrigatoriedade do ensino de $1^{\circ}$ grau - ensino fundamental. "Art. 18 . O ensino de $1^{\circ}$ grau será obrigatório, integrando-se no sistema escolar da Unidade Federativa" (BRASIL, 1984).

É importante mencionar que a Lei de Execução Penal, à luz dos preceitos Constitucionais, expressa que o preso conserva todos os direitos não atingidos pela perda da liberdade, lei ou sentença. Em seu artigo $3^{\circ}$ é descrito que "ao condenado e ao internado serão assegurados todos os direitos não atingidos pela sentença ou pela lei”.

Posteriormente, no ano de 2009 o Conselho Nacional de Politica Criminal e Penitenciaria, por meio da Resolução $n^{\circ}$ 3, aprovou e instituiu as diretrizes para a oferta de educação em estabelecimentos penais. À vista dessa, já no cenário da normatização educacional, o Conselho Nacional de Educação / Câmara de Educação Básica, por meio da Resolução n 2 de 2010, também legitimou essas diretrizes, cujas orientações foram baseadas em diferentes documentos como a Constituição Federal de 1988, a Lei de Execução Penal de 1984 e os tratados internacionais firmados pelo Brasil, buscando assim atender suas especificidades. Conforme descrito na Resolução $n^{\circ} 2$ de 2010 do CNE/CEB:

Considerando o disposto na Constituição Federal de 1988, na Lei $n^{\circ} 7.210 / 84$, bem como na Resolução $n^{\circ} 14$, de 11 de novembro de 1994, do Conselho Nacional de Política Criminal e Penitenciária, que fixou as Regras Mínimas para o Tratamento do Preso no Brasil; Considerando o que foi aprovado pelas Conferências Internacionais de Educação de Adultos ( $\mathrm{V}$ e $\mathrm{VI}$ CONFINTEA) quanto à "preocupação de estimular oportunidades de aprendizagem a todos, em particular, os marginalizados e excluídos", por meio do Plano de Ação para o Futuro, que garante 
o reconhecimento do direito à aprendizagem de todas as pessoas encarceradas, proporcionando-lhes informações e acesso aos diferentes níveis de ensino e formação; (BRASIL, 2010, p.1).

Seguidamente, no ano de 2014, após quatro anos de negociações, debates, conferências regionais e estaduais, e um consenso possível de jogo político, é decretada e sancionada a lei federal $\mathrm{n}^{\circ}$ 13.005, aprovando o atual Plano Nacional de Educação - PNE e conferindo outras providencias. Nessa perspectiva, no texto do PNE, na meta 9.8, é descrito que deve

assegurar a oferta de educação de jovens e adultos, nas etapas de ensino fundamental e médio, às pessoas privadas de liberdade em todos os estabelecimentos penais, assegurando-se formação específica dos professores e das professoras e implementação de diretrizes nacionais em regime de colaboração (BRASIL, 2014, p.69).

Já na meta 10.10 deste Plano Nacional de Educação, traz a educação prisional, introduzido à meta de "orientar a expansão da oferta de educação de jovens e adultos articulada à educação profissional, de modo a atender às pessoas privadas de liberdade nos estabelecimentos penais [...]" (BRASIL, 2014).

Por fim, cabe aqui trazer a Lei $n^{\circ} 13.163$ do ano de 2015 (BRASIL, 2015), que realizou a alteração da Lei no 7.210 do ano de 1984 (Lei de Execução Penal), e fortaleceu a discussão em torno do direito à educação aos sujeitos privados de liberdade, na medida que dispôs sobre a necessidade de tanto o ensino fundamental quanto o ensino médio serem oferecidos aos sujeitos em situação de privação de liberdade nos estabelecimentos prisionais, aumentando, assim, os anos e níveis de educação ofertados.

Em face ao descrito, pode se perceber a presença de diversos referenciais normativos que buscam assegurar a oferta e o direito da educação prisional. Nessa perspectiva, Onofre e Julião (2013), salientam que o Brasil já superou o momento de pleitear o direito a educação prisional, estando agora no estágio de analise das suas praticas e experiências, buscando estabelecer programas, consolidar politicas e propostas. Diante disso, concorda-se com os referidos autores ao afirmarem que é o momento de se avaliar efetivamente os resultados da educação prisional.

Tendo em vista essa perspectiva, vale recordar que na educação prisional são oferecidas diferentes disciplinas, dentre elas temos a Educação Física, que constitui componente curricular obrigatório da educação básica (Lei 9.394/96), com suas características e necessidades específicas. De acordo com llha (2012), constituem exemplos de características específicas da Educação Física o espaço físico no qual geralmente se tem para as aulas da disciplina e a importância de materiais nas ações educativas dos professores.

À vista desses aspectos, torna-se se relevante refletir sobre a atuação de professores de Educação Física em escolas prisionais, no que concerne a análise das práticas desses professores, seus desafios e possibilidades. Dessa maneira, essa investigação intencionou identificar e analisar possíveis desafios enfrentados por professores de Educação Física atuantes em escolas prisionais. 


\section{METODOLOGIA}

Este estudo se caracterizou como uma pesquisa de natureza qualitativa na qual, de acordo com Minayo (2011), trabalha-se com um universo de significados, motivos, aspirações, crenças, valores e atitudes. Isso corresponde a um espaço mais profundo das relações, dos processos e dos fenômenos, que não podem ser reduzidos à operacionalização de variáveis. A escolha pela abordagem qualitativa foi para assegurar contato próximo e direto com os sujeitos que ocorrem naturalmente e são muito influenciados pelo seu contexto (LÜDKE; ANDRÉ, 2013).

Participaram dessa investigação três professores de Educação Física das três unidades prisionais convencionais da região elegida para o estudo, denominada Região dos Inconfidentes. A escolha dessa região ocorreu pela intenção de contribuir para compreensão de uma problemática regional, oferecendo um retorno às cidades envolvidas. Essas unidades prisionais estão localizadas nas cidades de Mariana, Ouro Preto e Ponte Nova, no estado de Minas Gerais.

Destaca-se, ainda que estes participantes compõem todos os professores de Educação Física da região elegida, reforçando a relevância da abrangência da investigação. Os selecionados são professores em início de carreira (GONÇALVES, 2007). Os nomes dos professores aqui adotados são fictícios, buscando preservar o anonimato dos mesmos.

Para análise dos dados, utilizou-se a técnica de análise de conteúdo que, segundo Bardin (2009), remete a um conjunto de técnicas de análise das comunicações visando obter, por procedimentos sistemáticos e objetivos de descrição do conteúdo das mensagens, indicadores quantitativos ou não que permitem a inferência de conhecimentos relativos às condições de produção/recepção - variáveis inferidas - destas mensagens.

Após a coleta dos dados, efetuou-se a transcrição na íntegra das entrevistas que foram gravadas com um gravador de voz. Dessa forma, após a análise interpretativa dos dados, delimitou-se algumas categorias de análise que foram articuladas com teorias de estudos já desenvolvidos.

\section{RESULTADOS E DISCUSSÕES}

Os professores de Educação Física estão inseridos em um cenário em que vão se defrontar com diferentes desafios em suas práticas docentes, no qual vão atuar dentro das possibilidades que as escolas prisionais Ihes oferecem.

Um primeiro aspecto que surge nos relatos dos professores refere-se ao olhar negativo da sociedade sobre a educação prisional e a atuação docente na mesma, que desencadeia repercussões na realidade das escolas no cárcere. Para o docente Teodoro, parece estar presente no imaginário das pessoas um olhar preconceituoso com relação à educação dos sujeitos em situação de privação de liberdade. Geralmente não reconhecem a educação como um direito e nem percebem a importância da mesma na vida desses indivíduos, conforme exposto no excerto a seguir: 
Esse preconceito ele vem de, poxa você vai dar aula para um preso? Muitas pessoas não acreditam na reabilitação social de um preso, as pessoas não acreditam nisso, vê isso como uma situação de, poxa folga do cara, que folga do preso, já está preso e tem comida, tem a roupinha lavada e tal, não sei, e ainda vai ter uma escola, um direito de escola. Muitas pessoas não enxergam isso como um direito, muitas pessoas não enxergam isso como um agente de transformação [...] (Teodoro).

Nesse âmbito, a pesquisa que tematiza sobre o sistema penitenciário brasileiro desenvolvida por Andrade e Ferreira (2016), indica que a sociedade tem nutrido um olhar desacertado sobre o sistema prisional, como se os sujeitos em situação de privação de liberdade ficassem encarcerados perpetuamente. Nas palavras dos referidos autores, se faz presente uma visão cultural na sociedade de que apenas encarcerar as pessoas nos estabelecimentos prisionais é o bastante para apartar os problemas dos que estão do lado de fora. Essa ideia parece exercer influências dentro das prisões, através das concepções e ações dos agentes de segurança prisional defronte a educação nesse cenário, conforme apontam os professores participantes dessa pesquisa Teodoro e Kalebe:

Muitos e grande maioria [...] de 0 a 10 ai, 9 desaprovam [...] Eles acham que é uma situação de folga para o preso né, eles não acreditam que o preso pode se reabilitar, possam ser transformados. Eles acham, eles lidam como se fosse, alguns, não são todos, desses nove que eu falei [...] Eles acreditam que é um momento de [...] folga deles, uma coisa sem ter merecimento. [...] eles acreditam que isso é errado, eles não acreditam que isso é transformador. (Teodoro).

[‥] o agente penitenciário não tem muita, não quer muita influencia com o que acontece lá dentro, portanto para eles aqueles presos que estão lá tem que ficar é preso, não tem que ter aula não tem que ter nada. [...] o desinteresse de dentro do presídio é muito grande, o desinteresse do sistema prisional, do preso ser diferente, ser estudado é totalmente diferente, eles não querem que eles sejam assim. (Kalebe).

Percebe-se nesses relatos o desinteresse e a falta de apoio dos agentes de segurança prisional às atividades educacionais nas escolas das prisões e o não reconhecimento da educação como um direito dos sujeitos em situação de privação de liberdade. Tendo em vista esses relatos, subtende-se que esses agentes desaprovam e desacreditam da importância da educação na vida dos indivíduos privados de liberdade 
Posto isso, é importante lembrar que, de acordo com a Constituição Federal de 1988, a educação é um direito público subjetivo, e dessa forma, ninguém pode ser impedido de usufruir desse direito. Todavia, Salvalaggio (2016) em sua investigação sobre a organização do trabalho pedagógico na prisão, reitera que apesar da educação prisional ser legitimamente um direito, a mesma é compreendida pelos funcionários dos sistemas prisionais como um privilégio aos presos.

Essa concepção acarreta variadas consequências nas atividades pedagógicas dos professores nas escolas prisionais, sendo relatados pelos docentes diferentes dilemas com os agentes de segurança e direção do estabelecimento prisional.

[...] eles até se omitiam na hora de tirar os presos, fingiam que não estavam lá na hora, eu acho até para ter menos trabalho, não sei, às vezes estou até julgando errado, mas a conversa era essa, que a gente achava que eles achavam ruim de ter que ir lá arrumar um trabalho a mais em tirar os presos das celas para estudar, e atrasavam muito as aulas por causa disso. Porque às vezes a aula começava, minha aula no caso começava oito e quinze, mas às vezes nem tinha aula porque eles não soltavam os presos, falavam que tinha pouca gente, que não tinha como. (Raimundo).

[...] às vezes, o agente penitenciário está com raiva do cara e não pega o cara para ele vim para a sala de aula. [...] Porque o aluno não está aqui? "A porque ele dormiu mais!". Mas ai o outro aluno vem e me conta, "não, não deixaram ele sair". Então, quer dizer, é um tipo de vingança entendeu, e eu acho que isso não era para acontecer, mas acontece. (Kalebe).

[...] existe uma situação até de regra para os alunos frequentarem a escola, o que acontece, determinado agente, se ele identificou que o aluno, que o preso, o aluno que vai frequentar a escola não está com sua higiene em dia, ele retém o aluno na cela, seja por o motivo de uma unha não cortada, por um cabelo que não está cortado adequadamente, ou uma higiene pessoa inadequada. Os agentes costumam reter os alunos dentro da cela e não levalos para a sala. (Teodoro).

Observa-se nos relatos supracitados a queixa de omissão dos agentes de segurança prisional no que se refere à condução dos sujeitos em privação de liberdade para as salas, ocasionando atrasos ou cancelamentos das aulas pelo fato dos alunos não chegarem para as mesmas. Os dados de uma pesquisa sobre as políticas públicas educacionais voltadas à educação no ambiente prisional, produzida por Boaretto (2013), convergem para a mesma direção do nosso estudo, relatando a situação de atrasos e ausências dos alunos para as aulas na escola prisional sendo desencadeados por negligência dos funcionários de segurança.

Reflexão e Ação [ISSN 1982-9949]. Santa Cruz do Sul, v. 27, n. 2, p. 130-147, mai./ago. 2019. 
Nesse âmbito, Bessil (2015), em sua investigação sobre a dinâmica saúde e sofrimento mental vivida por professores na educação prisional, revela que "a organização do trabalho do docente que depende da autorização e organização do trabalho da segurança gera certa frustração por parte dos docentes" (p.126). A afirmação da autora repercute na percepção de professores de nosso estudo, ao expressarem uma ideia de inexistência de autonomia docente nas escolas prisionais, ao terem que se adequar ao que thes são exigidos pelo estabelecimento penal, que não leva em consideração os pontos de vista desses professores. Essa situação ocasiona frustação e insatisfação aos professores, conforme relatam os docentes Kalebe e Raimundo:

Infelizmente o sistema prisional fala pra você o seguinte: ou você faz assim ou não tem outro jeito, então você tem que agir da maneira que eles querem, você tem que trabalhar da maneira que eles querem. Só que eu tento modificar isso com meu jeito de trabalhar, mas na norma deles, não tem como mudar. [...] os professores tem que se virar para enquadrar ao que eles querem, mesmo a gente dando ideias que poderiam melhorar, as nossas ideias são cortadas ao meio. (Kalebe).

[...] eu utilizo do que tem lá, eu não consigo implantar todos os conteúdos, eu não tenho infraestrutura suficiente para implantar todos os conteúdos da Educação Física. Então é o presídio que me dá o que eu tenho que implantar no ano, eu implanto o que tem como[...] (Raimundo).

Para mais, Vieira (2013), em seu trabalho sobre o cotidiano e a cultura escolar da prisão, nos informa que as atividades realizadas na rotina de uma escola prisional são carregadas pelo imprevisível, e ainda que sejam planejadas e determinadas, não é garantido executá-las como planejava. Nesse contexto de imprevisibilidade das escolas prisionais, o professor Raimundo, participante de nosso estudo, revela a ocorrência de acontecimentos inesperados no estabelecimento prisional, que influenciam diretamente no planejamento pedagógico de suas aulas na escola prisional e na rotina e comportamento dos alunos. Esses episódios são destacados em seus relatos:

Um dia, por exemplo, em que tem uma rotina de procedimentos antes lá, que fiscalizam as celas, me parece, nos outros dias eles estão muito estressados [...] tem uma revista dentro de todas as celas, e ali já ouvi falar que jogaram material escolar fora já, e acham não sei o que. Já ouvi que são mordidos por cachorro, várias coisas que acontecem, por exemplo. E ai quando muda isso ai, eu não sei se é correto, eu não vou julgar como o procedimento é feito [...] os alunos ficam muito estressados, você vê na cara deles que eles já não estão tão pacientes para nada, já chega balançando a cabeça, sem querer 
conversar, sem fazer nada [...] e ai influencia diretamente nas aulas. (Raimundo).

[...] acharam um pé de maconha lá no presídio, ai poxa foi aquela maior confusão e tudo, e infelizmente ficaram quinze, vinte dias sem aula, aí quando voltaram estava o maior "bafafá", maior caos, porque eles falaram que foram mordidos por cachorro, que apanharam, que não sei o que, que não sei o que sei lá, mudou totalmente nossa rotina, a rotina deles, aquela progressão que você tinha foi interrompida. (Raimundo).

Outro caso foi de um principio de motim lá, botaram fogo no colchão lá dentro, e você ficava lá sem saber o que estava acontecendo direito. (Raimundo).

Denota-se, também, outro desafio nas falas dos professores, que se refere à falta de apoio da escola a qual o docente atuante na escola prisional é funcionário. Os professores Kalebe e Raimundo relatam que não contam com efetivo apoio, nem da equipe pedagógica nem da direção escolar, sendo que, muitas vezes, a escola exerce somente cobranças burocráticas como, por exemplo, solicitação de avaliações e fechamento de diário e notas, não fornecendo, além disso, apoio a esses professores. Estes docentes se indagam e questionam tal situação:

Então nos temos um apoio pedagógico, sim pedagógico, até o limite que interessa para a escola dali para lá não. Para a escola tem que apresentar fichário pronto né, tudo prontinho, tudo fechadinho para poder a escola receber a verba. Agora o apoio que você precisa para dar aula não. É difícil! [...] na hora que a gente precisa, se a gente precisa e a gente não fazer de própria vontade a gente não consegue. (Kalebe)

Na verdade eu não tive muito apoio pedagógico. [...] Hoje em dia tem a pedagoga lá, a gente não tem nenhum... a gente não senta para planejar aula, ela não cobra planejamento, é... não tem nenhum apoio pedagógico em relação a isso. (Raimundo)

Cabe aqui descrever que os relatos de falta de apoio recebido por esses professores, que são iniciantes, nos conduzem a uma ideia de que esses docentes estão imersos em um cenário em que se encontram isolados, como se estes estivessem invisíveis, assim como os sujeitos em privação de liberdade parecem estar para a sociedade. Cardoso (2016), em seu estudo sobre o acompanhamento docente de professores em início de carreira, aponta a falta de acolhimento e apoio da escola aos professores iniciantes, levando estes a um isolamento profissional. Todavia, André (2012), em seu 
trabalho sobre politicas de apoio a professores iniciantes, destaca que é indispensável atenção especial aos professores iniciantes, para que estes se sintam menos sozinhos e recebam o suporte necessário para vencer as possíveis dificuldades do inicio de carreira docente.

Analisando os dados coletados neste estudo, percebemos outro empecilho enfrentado pelos professores, no que se refere à falta de reconhecimento dos professores das outras disciplinas sobre a Educação Física e seu professor. Nos relatos dos docentes têm-se a indicação de um olhar negativo dos seus pares sobre a Educação Física no contexto escolar. Conforme pode-se identificar no excerto a seguir:

[...] tem a visão que a Educação Física é um momento de brincadeira, de palhaçada, de que não é realmente uma matéria que tem conteúdo programático [...] $A$ visão que eu acho que eles têm, que eles veem a Educação Física é essa, que matemática e português, por exemplo, é muito mais importante para eles e para todo mundo. [...] eu tive um fato de eu estar numa aula de Educação Física e uma professora gritar "o pessoal vamos sair do recreio ai, vem cá estudar". (Raimundo).

A partir desse excerto, cumpre aqui ressaltar que Gariglio e Reis (2016), ao analisarem os dilemas e aprendizagens docente de professores de Educação Física iniciantes, nos explicam que se tem uma ampla dificuldade dos atores escolares reconhecerem a disciplina de Educação Física como um espaço de aprendizado sistemático, com objetivos singulares e significativos para o desenvolvimento dos alunos. Sob a óptica dos referidos autores, o quadro atual da Educação Física na escola é marcado, em sua grande maioria, por situações de desrespeito à Educação Física e seus professores.

Além destes desafios apresentados, os professores participantes desse estudo revelam uma condição negativa específica à Educação Física, no que se refere ao local ao qual acontecem as aulas das escolas prisionais. Os professores indicam que as aulas de todas as disciplinas, inclusive as de Educação Física, acontecem somente dentro das salas, sem nenhum outro espaço para o desenvolvimento das mesmas. Destaca-se que este representa um dilema especifico do professor de Educação Física, em virtude das características e necessidades próprias da disciplina. Essa situação pode ser observada na fala dos professores Teodoro e Raimundo:

Porque como eu tenho uma limitação de espaço, uma limitação física muito grande, eu tenho apenas uma sala pequena para trabalhar [...] Por não se tratar de uma escola regular, existe a limitação espacial né. Então é uma situação que é uma escola que oferece o que ela pode né [...] lógico que tem 
suas limitações. [...] tem a situação de estar em um ambiente prisional, dentro de uma sala, em que se é permitido apenas dentro daquela sala.(Teodoro).

Então, quer dizer, é uma sala só, é uma cela com grade e tudo, tem um banheiro lá dentro e tem dois quadros na mesma sala. Então não tem divisão de sala, nem nada. (Raimundo).

Se referindo à precária infraestrutura física das prisões, Miranda (2016), em seu estudo sobre as contribuições da educação prisional para a ressocialização de mulheres encarceradas, revela que as práticas escolares nesse contexto geralmente acontecem em espaços inadequados, com outras finalidades ou de utilização compartilhada com outras destinações. Esse deficiente cenário das escolas prisionais nas quais atuam, fazem com que os professores se questionem de como desenvolver suas aulas de Educação Física somente dentro de sala - cela ${ }^{4}$, conforme descrito nos relatos dos professores Kalebe, Teodoro e Raimundo:

Porque dentro de uma sala de aula de menos de quarenta metros quadrados, que hoje formaram duas salas nesses quarenta metros quadrados. [...] é meio frustrante, porque como é, como que você vai fazer? Tem as carteiras, tem livros, têm não sei o que, como você vai fazer com uma aula de Educação Física? (Kalebe).

[...] eu tenho apenas uma sala de aula cheia de carteiras, cheias de mesas, cadeiras, é aonde eu tenho que afastar tudo, que já limita um pouco o espaço até para os alunos jogarem, mas é o que foi ofertado e é o que pode ser feito lá. (Teodoro).

[...] na cela não tem espaço [...] as aulas são divididas, quer dizer, tem professor dando aula do meu lado falando sobre uma coisa e eu falando sobre outra coisa do lado dele, tipo assim, a menos de cinco metros de distância [...] é complicado na verdade [...] A regra deles é que eles não podem sair dessa cela [...] ai não tem como [...](Raimundo).

Pode se perceber no relato do professor Raimundo, um agravante para as aulas de Educação Física em relação aos demais professores participantes da pesquisa, em que as aulas além de acontecerem somente dentro de sala o espaço é dividido com outro professor e sua respectiva turma, sem nenhuma separação entre as mesmas. Em relação a essa questão, o estudo na temática do ensino da Educação Física e as condições materiais para as ações pedagógicas de seu professor, desenvolvido por Damazio e Silva (2008), indica que o espaço físico e as instalações inadequadas para

\footnotetext{
${ }^{4}$ Os professores participantes desse estudo, muitas vezes, se referem as salas de aula como "celas de aula".
} 
as aulas constituem-se como fatores que podem prejudicar significativamente o trabalho pedagógico da Educação Física.

Além dessas limitações físicas, outro aspecto que restringe as ações dos professores de Educação Física nas escolas prisionais, segundo os professores de nosso estudo, diz respeito às regras dos estabelecimentos prisionais, que proíbem ou restringem o uso de diversos materiais como ferramenta pedagógica para suas aulas. Não lhes são permitidos materiais geralmente utilizados na Educação Física, como pode se citar, por exemplo, cordas, bolas, bambolês (arcos), materiais do atletismo, e, também, nada que cause corte ou que seja pontiagudo.

Hoje eu não tenho nada de Educação Física para usar, nenhuma corda porque não pode, nenhum bambolê, nenhum pneu, nada, o que eu preciso eu não posso usar [...]Não pode ser lata, não pode ser nada que tem, que possa causar um corte, nada disso pode ser colocado. [...] e nem que amarre, a corda né, de jeito nenhum! (Kalebe).

[...] eu não posso levar uma bola, não posso levar uma peteca, eu não tenho nada que tenha muito movimento que eu possa fazer lá. [...] não posso adentrar com corda, do atletismo não posso entrar com o dardo, lá tem essas limitações [...] eu não posso levar nada de pontiagudo [...] futebol de [...] prego sabe, que tem um monte de prego, era um que proibiram de levar, até cogitei a levar [...](Raimundo).

[...] não que falte pela escola, mas, do que se é permitido lá dentro. Porque a escola oferta, mas não tem como praticar e também porque não é uma situação possível pela direção do próprio presídio. [...] uma bola, materiais, por exemplo [...] eu não pude levar os grampos que sustentam a rede porque contém metal, ferro, o que não é permitido dentro da sala [...] porque são materiais que viram "fincos" né, e isso a direção não permite. (Teodoro).

É apontado, ainda, que além das limitações materiais enfrentadas na escola prisional, os professores também encontram restrições relacionadas à estratégia didática a ser utilizada. Segundo relata o professor Kalebe, não se permite ao professor trabalhar com qualquer estratégia que envolva competição ou disputa entre os alunos nas aulas de Educação Física. Segundo o professor:

No estabelecimento eu não posso fazer nenhum conteúdo que tenha alguma atividade de disputa, então é proibido. Não se pode disputar, então eu não posso criar jogo que tenha disputa, então, por exemplo, eu queria criar jogos internos do presídio, eles não deixaram.[...]Eu não posso criar competição entre eles, para não dar "rincha", então me foi proibido. (Kalebe). 
Diante desse contexto, ao tematizar sobre a organização do trabalho docente no cárcere, Salvalaggio (2016) explica que a escola inserida na prisão funciona de maneira que tem que obedecer as regras de segurança definidas pelo estabelecimento prisional. A autora afirma que as oposições entre a educação e as normas de segurança, dificultam significativamente as atividades pedagógicas planejadas e previstas.

Nesse âmbito, ao pesquisar a prática docente em escola prisional, Bessil (2015), expõe que as ações da escola prisional e da docência neste contexto vão ser prescritas pelas inflexíveis normas de segurança, disciplina e disposição interna dos estabelecimentos prisionais.

Assim sendo, cabe aqui trazer uma análise entre a Educação Física e as outras disciplinas escolares realizado por Pinto e Vaz (2009), em seu estudo que discute sobre a problemática entre saber e práticas corporais nas suas aulas da disciplina:

Dizem também que o movimento corporal nas aulas de Educação Física é permitido, enquanto nos outros espaços ele seria controlado, vigiado e reprimido. Cultiva-se aí uma outra crença: a de que a Educação Física é o lugar para os alunos se soltarem, compensando, pelo movimento corporal, a imobilidade e a fadiga provocadas em outros espaços escolares. (p.263).

Essa concepção de que na Educação Física os movimentos corporais são permitidos e que nesta os alunos podem se soltar, a partir dos relatos dos professores de nossa pesquisa, não se faz presente na realidade das escolas prisionais. Pelo contrário, nas mesmas, este movimento corporal é controlado assim como nos outros espaços escolares e durante as aulas de outras disciplinas. Nesse cenário das escolas prisionais vão ser limitadas as atividades e conteúdos da Educação Física realizadas dentro de sala de aula, como argumenta o professor Raimundo:

[...] olha na cela não tem espaço, eu divido com outro professor a minha aula, correr não tem como, pular não tem como, jogar uma bola não tem como, $e$ ai, obviamente, eu falei assim: olha, eu tenho que fazer alguma coisa [...] (Raimundo).

Efetua-se, assim, uma situação contraditória, pois se parte da premissa de que quando se pensa em Educação Física, consequentemente se pensa em movimento, através de exercícios ou atividades físicas 5 . Situação esta que não ocorre nas aulas de Educação Física das escolas prisionais de nossos participantes, como ilustra os relatos dos professores Kalebe e Raimundo:

\footnotetext{
${ }^{5}$ Os termos aqui empregues são de acordo com o sentido descrito no Glossário temático - Promoção da Saúde, do Ministério da Saúde, que define atividade física como movimento corporal que produz gastos de energia acima dos níveis de repouso; Já exercício físico entendido como toda atividade física planejada, estruturada e repetitiva.
}

Reflexão e Ação [ISSN 1982-9949]. Santa Cruz do Sul, v. 27, n. 2, p. 130-147, mai./ago. 2019. https://online.unisc.br/seer/index.php/reflex/index 
Porque ficar dentro da sala de aula, sem sair para nada [...] E se é uma aula de Educação Física põe que se a entender que é uma atividade física [...] (Kalebe).

Então nada que se diz respeito a exercício físico eu consigo fazer lá dentro, porque é uma sala de aula regular onde nem a porta é aberta, é uma grade, então não tem como fazer nada. (Raimundo).

Nessas circunstâncias, em face de suas limitadas possibilidades, percebe-se nos relatos dos professores que as aulas teóricas, sobre diferentes assuntos, são predominantes, citando, dentre os temas dessas aulas, discussões sobre primeiros socorros, alimentação, doenças crônicas e saúde. Como pode se perceber no relato do professor Kalebe:

Eu trabalho muito teoria [...] eu falo muito sobre primeiros socorros, [...] como identificar uma pessoa que tem a pressão arterial alta, como ela se sente; como tratar um diabético de repente [...] eu falo sobre alimentação, porque eles reclamam muito da alimentação deles, e eu falo o que eles podem fazer para melhorar, mesmo com a alimentação que eles têm, para poder diminuir peso, e sobre atividades que eles podem fazer dentro da cela [...](Kalebe).

Apesar dos diversos dilemas enfrentados cotidianamente em suas práticas docentes nas escolas prisionais, os professores Raimundo e Teodoro relatam sentir prazer e honra em serem professores de escola prisional. Revelam a situação de se sentirem desafiados com a possibilidade de mudanças de vida dos alunos, conforme destacam os excertos:

Hoje eu me sinto muito honrado em trabalhar lá, pelo público que eu trabalho, pela dificuldade que é, assim, só consegue ver quem trabalha lá as limitações que a gente tem [...] Isso é uma das coisas que eu me sinto muito desafiado em relação a poder mudar o cotidiano deles.[...] a minha maior realização eu acho que é essa, saber que algumas pessoas, por exemplo, eu já vi mudança neles lá dentro. Então também é muito bom. (Raimundo).

Nossa, muito bem. Muito bem! A ver que eu pude colaborar um pouco para que eles transformassem a vida deles de maneira significativa, eu me sinto muito bem, é o prazer, é o reconhecimento que um professor tem mesmo se tratando de uma unidade prisional. (Teodoro). 
Em uma situação semelhante à encontrada em nossa investigação, o estudo desenvolvido por Almeida (2014), sobre as representações sociais de professoras atuantes no cárcere, revela que "embora atuando em local inóspito, enfrentando situações adversas durante o exercício do ofício [...] os sujeitos de ensino têm maior satisfação e sentem prazer em exercer a docência na escola prisional" ( $p$. 215).

Além disso, constata-se nas falas dos professores Kalebe e Raimundo a indicação de um grande respeito dos alunos pelos professores nas aulas ministradas nas escolas prisionais. Destacam que, muitas vezes, os alunos das escolas prisionais têm mais respeito pelo professor do que alunos das escolas regulares. Conforme excertos a seguir:

Eu achei mais normal, assim, dar aula dentro de um presídio, melhor que dar aula dentro da escola, porque o respeito dentro do presídio, do aluno como detento, é maior do que o aluno dentro da sala de aula normal. Então eu acho que a diferença entre fora e dentro do presídio está nisso ai, lá eles são obrigados a respeitar, aqui fora infelizmente os professores sofrem muitos problemas com os alunos que não respeitam. (Kalebe).

[...] eu me sinto muito respeitado e acho que eles até gostam bastante das aulas de Educação Física né [...] ao longo do tempo eu fui vendo que realmente o pessoal que está lá tem respeito pela gente [...] veem que nós somos pessoas que estamos lá para poder reinserir eles na sociedade, para pode ensinar alguma coisa para eles que talvez não tiveram essa oportunidade. (Raimundo).

Os resultados do estudo de Barcelos (2017), que pesquisou a respeito da atuação de professoras em escolas prisionais de uma cidade do Mato Grosso do Sul, convergem com os de nossa pesquisa, no qual, as professoras entrevistadas pelo autor, descrevem que é mais fácil dar aula na escola dentro do cárcere do que fora; que se sentem mais realizadas nas suas ações docentes na prisão do que em escolas externas; tendo, ainda, relatos de que na escola prisional os alunos respeitam os professores, são mais educados e valorizam estar na escola.

Nessa perspectiva, em situação semelhante à de nosso estudo, Bessil (2015), revela que os professores de sua investigação, atuantes em escolas prisionais, expressaram, repetidamente, "a questão da disciplina existente por parte dos alunos dentro do presídio, disciplina essa que segundo o relato dos entrevistados não é vista no ensino regular, outro motivo que por si só já garante a satisfação de trabalhar dentro de uma unidade penal" (p.159). 


\section{CONSIDERAÇÕES FINAIS}

Diante do cenário apresentado, cumpre aqui descrever que os professores de Educação Física encontram diversos desafios em suas atividades docentes nas escolas prisionais. Desafios relacionados ao olhar da sociedade que têm influências nas escolas prisionais em função do desinteresse dos agentes de segurança prisionais; falta de autonomia dos professores nas escolas prisionais; falta de apoio da escola; não reconhecimento da importância da Educação Física pelos professores das outras disciplinas; precarização física estrutural.

Além destes, um desafio específico da Educação Física, que se refere às aulas acontecerem somente dentro de sala e ainda com diversas restrições com limitação de movimentos e práticas corporais. Essa situação faz com que as aulas teóricas de variados conteúdos sejam predominantes. Assim, apesar de encontrar limitações em suas ações docentes, faz se importante a constante atualização profissional dos professores de Educação Física atuantes nas escolas prisionais, em razão de que estratégias de gestão junto a essa modalidade de ensino podem ser otimizadas.

Essas circunstâncias limitam os professores em suas possibilidades e no alcance dos propósitos educacionais da Educação Física, engendrando um paradoxo, pois quando se pensa na disciplina pressupõe a presença de movimento e de práticas corporais. Questiona-se, assim, como os professores, através das aulas de Educação Física, vão alcançar os objetivos da disciplina, no sentido de promover o contato dos alunos em situação de privação de liberdade, com as diversas práticas corporais que constituem conteúdo da Educação Física, sendo as aulas realizadas somente dentro da sala e com diversas restrições?

Chama-nos a atenção o fato de que apesar de diferentes desafios e circunstâncias negativas às suas práticas docentes nas escolas prisionais, os professores participantes desse estudo revelam grande satisfação e honra em exercerem a docência nesse cenário. Destacam o grande respeito que os alunos têm por eles. Uma questão interessante nessa condição é que, para os professores, esta é uma situação diferente das escolas prisionais se comparando às escolas regulares, onde de acordo com mesmos não se faz presente esse respeito.

Todavia, reitera-se que apesar de se perceber esforços por meio das diferentes ações e normatizações publicadas ao longo da história, assim como as politicas para se estabelecer a educação nos estabelecimentos prisionais, ainda assim se faz presente diferentes impasses para a efetivação, nesse caso, da Educação Física nesse cenário. Assim, acredita-se que é necessário repensar questões a respeito da lógica de organização das escolas prisionais, através de mecanismos que reduzam os desafios e impactos na prática docente dos professores de Educação Física, favorecendo a prática educativa nesse contexto. 


\section{REFERÊNCIAS}

ALMEIDA, C. V. A. A professora nos entremuros do cárcere. 2014. 234f. Tese (Doutorado em educação e contemporaneidade) Universidade do Estado da Bahia, Salvador.

2. ANDRADE, U. S.; FERREIRA, F. F. Crise no sistema penitenciário brasileiro: capitalismo, desigualdade social e prisão. Revista Psicologia, Diversidade e Saúde, v. 4, n. 1, 2016.

3. ANDRÉ, M. Políticas e programas de apoio aos professores iniciantes no Brasil. Cadernos de Pesquisa, v.42, n.145, p.112-129, 2012.

4. BARCELOS, C. S. Da cela à sala de aula: a (não)formação de professores que atuam nos estabelecimentos penais de corumbá (MS). In: 38ª Reunião Anual da ANPEd. São Luís, 2017.

5. BARDIN, L. Análise de conteúdo. Trad. Luís Antero Reto e Augusto Pinheiro. 5. ed. Lisboa: Edições 70, 2009.

6. BESSIL, M. H. A prática docente de educação de jovens e adultos no sistema prisional: um estudo da psicodinâmica do trabalho. 2015. 217f. Dissertação (Mestrado em Psicologia social e Institucional) - Universidade Federal do Rio grande do Sul, Porto Alegre.

7. BOARETTO, K. C. Direito e Desafios: A Educação no Ambiente Prisional. 2013 254f. Dissertação. (Mestrado em Educação) - Universidade da Região de Joinville, Joinville.

8. BRASIL. Conselho Nacional de Educação. Resolução n² 2, de 19 de maio de 2010. Dispõe sobre as diretrizes nacionais para a oferta de educação para jovens e adultos em situação de privação de liberdade nos estabelecimentos penais. Brasília, 2010.

Conselho Nacional de Política Criminal e Penitenciária (CNPCP). Resolução n 3, de 11 de março de 2009. Dispõe sobre as diretrizes nacionais para a oferta de educação nos estabelecimentos penais. Brasília, 2009.

Lei n. 9.394 de 20 de novembro de 1996. Estabelece as diretrizes e bases da educação nacional. 1996. Disponível em: http://www.planalto.-gov.br/ccivil_03/Leis/L9394.htm. Acesso em: 20 out. 2017. Plano Nacional da Educação, Lei n 13.005. Brasília, 2014. Presidência da Republica. Lei 13.163. Brasília, 2015. 

Pensar a Prática, v. 11, n. 2, p. 189 - 196, 2008. Educação Física. Rev. Diálogo Educ., Curitiba, v. 16, n. 50, p. 911-936, out./dez. 2016. (org.) Vidas de professores. Portugal: Porto Editora, p.141- 169. 2007.

19. ILHA, F. R. S. O professor iniciante e a educação física escolar: desafios que se somam. 2012; In: IX ANPEd Sul, Seminário de Pesquisa em Educação da Região Sul, p. 1-16, 2012. EPU, 2013.

21. MINAYO, M. C. S. (Org.) Pesquisa Social: teoria, método e criatividade. 30. ed. Petrópolis: Vozes, 2011.

22. MIRANDA, J. M. C. Educação de jovens e adultos: escola no cárcere e ressocialização de mulheres cearenses no regime semiaberto. 2016. 203f. Tese (Doutorado em Educação) Universidade Federal do Ceará, Fortaleza. Dissertação (Mestrado em Educação) Universidade Tuiuti Do Paraná, Curitiba. 
VIEIRA, E. L. G. A cultura da escola prisional: entre o instituído e o instituinte. Educação \& Realidade, v. 38, n. 1, 2013.

\section{Glauber Cesar Cruz Custodio}

Mestre em Educação pela Universidade Federal de Ouro Preto - UFOP. Possui Especialização em Educação Inclusiva pela Universidade Cândido Mendes. Graduado em Educação Física bacharelado pela Universidade Federal de Ouro Preto, MG. Graduado em Educação Física Licenciatura pela Universidade Federal de Ouro Preto. É membro do grupo de Pesquisa sobre Formação e Profissão Docente (FOPROFI/DEEDU/UFOP).

\section{Célia Maria Fernandes Nunes}

Possui graduação em Pedagogia pela Universidade Santa Úrsula, Mestrado em Educação Especial (Educação do Indivíduo Especial) pela Universidade Federal de São Carlos, Doutorado em Educação pela Pontifícia Universidade Católica do Rio de Janeiro e Pós Doutorado pela Universidade Federal de Minas Gerais. Atualmente é Professora Associada da Universidade Federal de Ouro Preto atuando na Graduação e Pós- Graduação. E vice Lider do Grupo de Pesquisa sobre Formação e Profissão Docente (FOPROFI/DEEDU/UFOP), membro do Grupo de Pesquisas sobre Condição e Formação Docente (PRODOC /FAE/UFMG), membro da Red Docente de América Latina y el Caribe (KIPUS) e Rede Latinoamericana de Estudos Sobre Trabalho Docente (Rede ESTRADO).

\section{Como citar este documento:}

CUSTODIO, Glauber Cesar Cruz; NUNES, Célia Maria Fernandes. A docência em "celas de aula": desafios dos professores de educação física em escolas prisionais. Reflexão e Ação, Santa Cruz do Sul, v. 27, n. 2, abr. 2019. ISSN 1982-9949. Disponível em: <https://online.unisc.br/seer/index.php/reflex/article/view/12600>. Acesso em: doi:https://doi.org/10.17058/rea.v27i2.12600. 